Гистология. Эмбриология. Цитология : учебник / Н.В. Бойчук [и др.] ; под ред. Э.Г. Улумбекова, Ю.А. Челышева. Изд. 4-е, перераб. и доп. - Москва : ГЭОТАР-Медиа, 2016. 927 c.

\title{
Язык: русский
}

ISBN 978-5-9704-3782-7

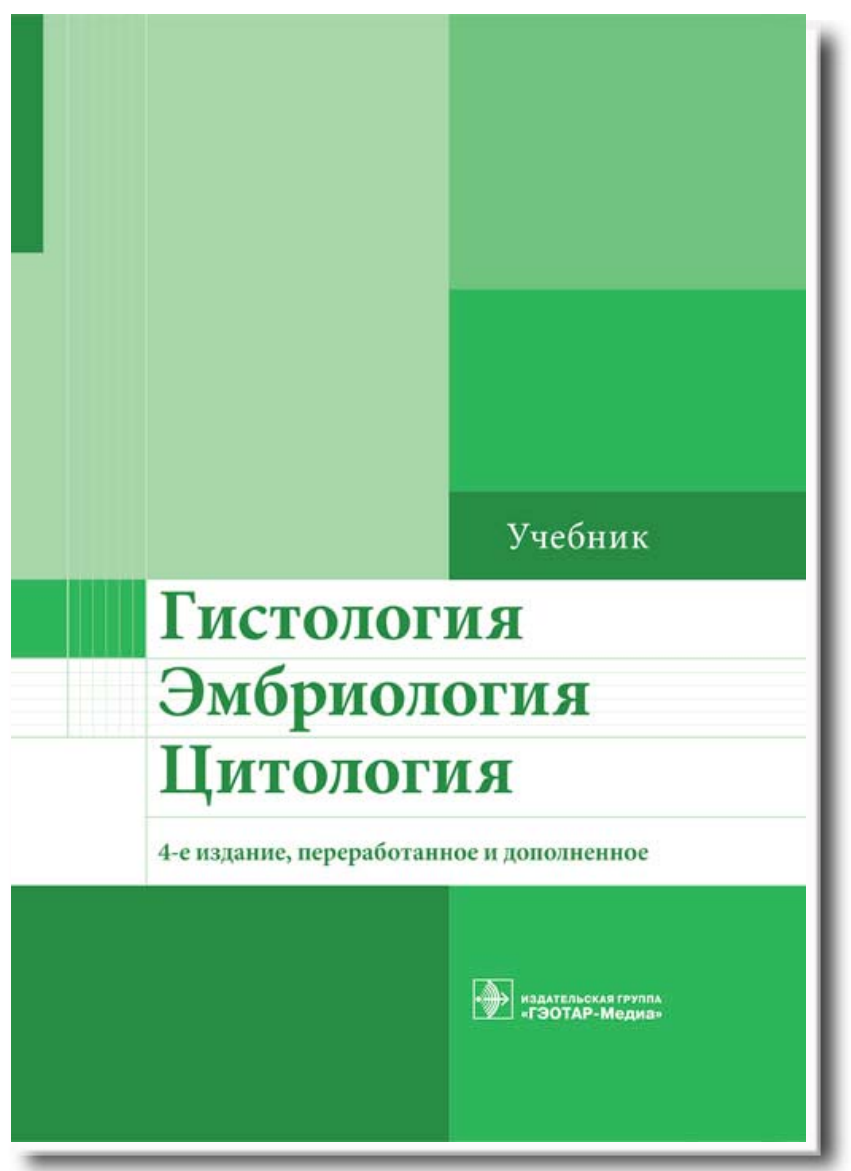

Четвёртое издание учебника переработано и дополнено в соответствии с учебными программами медицинских вузов по гистологии, эмбриологии и цитологии. Оно содержит 16 глав, включающих основные понятия дисциплины, их расшифровку и клинические детали, более 400 иллюстраций, а также контрольные вопросы и тестовый экзамен, материалы которых доступны в сетевом файле.

Рекомендовано ГБОУ ВПО «Первый Московский государственный медицинский университет имени И.М. Сеченова» в качестве учебника для студентов образовательных организаций высшего профессионального образования, обучающихся по направлениям подготовки «Лечебное дело», «Педиатрия», «Медико-профилактическое дело» по дисциплине «Гистология, цитология, эмбриология».

Учебник предназначен для студентов медицинских вузов. 